\title{
Flotation of high-grade fluorite in a short column under negative bias regime
}

\author{
W. Aliaga ${ }^{\text {a }}$, C.H. Sampaio ${ }^{\text {a,* }}$, I.A.S. Brum ${ }^{\text {b }}$, K.R.S. Ferreira ${ }^{\text {a }}$, M.A. Batistella ${ }^{\text {a }}$ \\ ${ }^{a}$ Centro de Tecnologia, Departamento de Engenharia de Minas, Universidade Federal do Rio Grande do Sul (UFRGS), Campus do Vale, \\ POA/RS, P.O. Box 15021, CEP 96500-970, Brazil \\ b DCTM, Escola Politécnica, Universidade Federal da Bahia, Brazil
}

Received 16 August 2005; accepted 12 February 2006

Available online 18 April 2006

\begin{abstract}
This paper presents flotation results carried out on fluorite ore using a relatively short column, operated under negative bias regime and without wash water. The term short column is used from a kinetic point of view from which collection zone comes out to be around $8 \mathrm{~m}$ tall (the relation height/diameter appears valid for industrial size columns). Negative bias was achieved making tailing flow smaller than feed flow. Hence, part of the water is carried up within bubbles wakes. No wash water is added.

It was found that, heavily loaded bubbles, formed in high-grade fluorite pulps, at negative bias, levitate easier than positive bias. Under such conditions, carrying capacity of columns seems to increase due to a decrease in downward velocity of pulp. Recovery increases considerably, resulting in a sort of rougher flotation. High recovery as well as grades was obtained under negative bias regime. (c) 2006 Elsevier Ltd. All rights reserved.
\end{abstract}

Keywords: Fluorite; Short column flotation; Negative bias regime

\section{Introduction}

Conventional column design was originally modeled from experimental data, fundamentally from sulfide ores. In such ores, valuable species are in small concentrations. However, for other minerals, such as industrial ones, the species of interest are in much higher concentrations. Due to that, it is probable that the conditions to float such ores might not be similar to sulfides. In this regard, many new designs have being proposed. Rubinstein (1995) claimed to have built a high capacity column, $5.5 \mathrm{~m}$ height by $9 \mathrm{~m}^{2}$ section, to float coal, which has been in operation since 1978 in the ex Soviet Union. Such a considerable difference with what has been claimed as conventional operation may be explained by differences in processed ores. With this in mind, column flotation of high-grade fluorite

\footnotetext{
${ }^{*}$ Corresponding author. Tel.: +55 513316 7067; fax: +55 5133167116 .

E-mail addresses: sampaio@ct.ufrgs.br, sampaio@ufrgs.br (C.H Sampaio).
}

was explored here at operating conditions different from those considered conventional for sulfide ores.

\section{Materials and methods}

\subsection{Mineral}

The fluorite ore used in this work came from Nossa Senhora do Carmo (NSC) Mining Co. from Criciúma city, Santa Catarina state, Brazil. The sample, as received, was $100 \%-20 \mathrm{~cm}$. It had some very large lumps of clay, which were hand picked and discarded. The rest of the sample was classified through a $1 / 2$ in.-opening sieve. The oversize was ground in a jaw crusher up to a size of $100 \%-1 / 2$ in. Then, all the ore was homogenized and divided by the coning and quartering and riffle until obtaining portions smaller than $2 \mathrm{~kg}$. Granulometric analysis for head sample are given in Table 1.

The chemical analysis gave $68.7 \% \mathrm{CaF}_{2}, 14.12 \%$ $\mathrm{SiO}_{2}$ and $3.92 \% \mathrm{CaCO}_{3}$, as main constituents. As minor 
Table 1

Composition of fluorite ore by granulometric fractions

\begin{tabular}{|c|c|c|c|c|c|c|}
\hline Fraction (mm) & Oversize $(\%)$ & Retained $(\%)$ & $\mathrm{CaF}_{2}$ grade $(\%)$ & $\mathrm{SiO}_{2}$ grade $(\%)$ & $\mathrm{CaCO}_{3}$ grade $(\%)$ & Weight loss $(\%)$ \\
\hline+8 & 10.11 & 10.11 & 76.87 & 11.80 & 3.15 & 2.30 \\
\hline$-8+4$ & 20.88 & 30.99 & 74.43 & 12.04 & 3.66 & 2.91 \\
\hline$-4+2$ & 11.97 & 42.96 & 63.48 & 16.03 & 5.04 & 3.05 \\
\hline$-2+1$ & 8.93 & 51.89 & 63.10 & 16.83 & 5.50 & 3.75 \\
\hline$-1+0.5$ & 9.98 & 61.87 & 67.91 & 16.44 & 3.42 & 3.48 \\
\hline$-0.5+0.25$ & 5.26 & 67.13 & 68.69 & 14.73 & 4.09 & 3.31 \\
\hline$-0.25+0.149$ & 4.94 & 72.07 & 72.72 & 12.89 & 4.20 & 3.30 \\
\hline$-0.149+0.074$ & 7.30 & 79.37 & 76.88 & 11.90 & 3.45 & 3.24 \\
\hline$-0.074+0.037$ & 4.65 & 84.02 & 64.36 & 10.99 & 4.26 & 5.50 \\
\hline-0.037 & 14.16 & 98.18 & 58.72 & 16.24 & 3.24 & 11.81 \\
\hline
\end{tabular}

constituents it presented some iron oxide, clays, feldspar and mica. Surface characteristics of fluorite were confirmed by zeta potential measurements corroborating literature data.

Grinding was carried out in a $19.8 \mathrm{~cm}$ diameter by $19.8 \mathrm{~cm}$ height cylindrical laboratory ball mill loaded with $12.825 \mathrm{~g}$ of steel balls. The load was composed by fortyfour $4 \mathrm{~cm}$ diameters balls plus eight $2 \mathrm{~cm}$ diameters balls and near $2 \mathrm{~kg}$ sample. Table 2 shows percentage of $+0.25 \mathrm{~mm}$ and $-0.074 \mathrm{~mm}$ particles for five grinding times while Table 3 shows mass and chemical composition of samples by granulometric fractions for three different grinding times. The grinding time used in this work was $20 \mathrm{~min}$ and the samples ground for such a length of time presented $11 \%+0.25 \mathrm{~mm}$ and $58.1 \%-0.074 \mathrm{~mm}$.

Table 2

Grindability tests

\begin{tabular}{lll}
\hline Grinding time $(\mathrm{min})$ & $>0.25 \mathrm{~mm}(\%)$ & $<0.074 \mathrm{~mm}(\%)$ \\
\hline 5 & 47.0 & 19.9 \\
10 & 27.0 & 42.8 \\
20 & 11.0 & 58.1 \\
30 & 3.0 & 67.7 \\
40 & 1.2 & 72.6 \\
45 & 0.6 & 77.2 \\
NSC mines feed & 0 & 74.7 \\
\hline
\end{tabular}

2.2. A Denver machine, model LA 500, with an acrylic cell, was used to determine flotation conditions

The pulp was prepared at $30 \%$ solid concentration. The pulp was conditioned at $900 \mathrm{rpm}$ and a $\mathrm{pH}$ around 10 . The reagents were added in the following order: First, sodium silicate ( $3 \mathrm{~min}$ conditioning), followed by cornstarch (5 min conditioning), next quebracho (Taggart, 1954) ( 3 min conditioning) and finally tall oil (3 min conditioning). Air was blown through the cell at a rate of $3 \mathrm{lpm}$, initially, which was increased stepwise till flow rate reached $6 \mathrm{lpm}$ at the end of the flotation, aiming to keep a froth layer constant (Table 4).

Table 4

Reagent addition scheme

\begin{tabular}{ll}
\hline Time span $(\mathrm{min})$ & Air flow $(\mathrm{lpm})$ \\
\hline $0-1$ & 3 \\
$1-3$ & 3 \\
$3-4$ & 4 \\
Water addition $(\mathrm{pH} 10)$ & \\
$4-8$ & 3 \\
Water addition $(\mathrm{pH} 10)$ & \\
$8-9$ & 4 \\
$9-10$ & 5 \\
$10-13$ & 6 \\
\hline
\end{tabular}

Table 3

Grades and size fraction at different grinding times

\begin{tabular}{|c|c|c|c|c|c|}
\hline Grinding time $(\min )$ & Size fraction $(\mathrm{mm})$ & Mass $(\%)$ & $\mathrm{CaF}_{2}$ grade $(\%)$ & $\mathrm{SiO}_{2}$ grade $(\%)$ & $\mathrm{CaCO}_{3}$ grade $(\%)$ \\
\hline 10 & $\begin{array}{l}+0.25 \\
-0.25+0.074 \\
-0.074+0.037 \\
-0.037\end{array}$ & $\begin{array}{l}27.0 \\
30.2 \\
13.3 \\
29.5\end{array}$ & $\begin{array}{l}61.15 \\
72.93 \\
71.32 \\
50.47\end{array}$ & $\begin{array}{r}18.20 \\
12.80 \\
9.44 \\
9.07\end{array}$ & $\begin{array}{l}3.03 \\
1.50 \\
2.86 \\
5.11\end{array}$ \\
\hline 20 & $\begin{array}{l}+0.25 \\
-0.25+0.074 \\
-0.074+0.037 \\
-0.037\end{array}$ & $\begin{array}{l}11.0 \\
30.9 \\
17.3 \\
40.8\end{array}$ & $\begin{array}{l}59.76 \\
73.12 \\
74.66 \\
52.37\end{array}$ & $\begin{array}{l}18.11 \\
12.80 \\
10.21 \\
11.39\end{array}$ & $\begin{array}{l}3.00 \\
2.30 \\
2.19 \\
5.00\end{array}$ \\
\hline 45 & $\begin{array}{l}+0.25 \\
-0.25+0.074 \\
-0.074+0.037 \\
-0.037\end{array}$ & $\begin{array}{r}0.6 \\
22.2 \\
19.5 \\
57.7\end{array}$ & $\begin{array}{l}- \\
61.74 \\
70.62 \\
64.06\end{array}$ & $\begin{array}{l}- \\
17.93 \\
12.48 \\
10.22\end{array}$ & $\begin{array}{l}- \\
2.97 \\
2.88 \\
2.70\end{array}$ \\
\hline
\end{tabular}




\subsection{Column cell flotation}

A house made modular column, constructed with three 1-m long, 4 in. diameter, PVC tubes, was used for the flotation tests. The pieces of tube were interconnected with threaded universal joints. Two pneumatic pumps controlled feed and tailings flows. The sparger was made of sintered stainless steel. The column had an inlet near to the bottom to inject a flow of water, which is called hear bias water $\left(J_{\mathrm{bw}}\right)$, aiming at varying negative biases, following the method described by Soto and Barbery (1991).

\section{Results and discussion}

\subsection{The prototype constructed for this work was submitted to a series of tests to check its performance}

For the sake of clarity, the term bias, $J_{\mathrm{b}}$, will be referred only to the difference between tailing and feed surface rates $\left(J_{\text {tail }}-J_{\text {feed }}\right)$. The value of $-0.3 \mathrm{~cm} / \mathrm{s}$ for $J_{\mathrm{b}}$ was chosen because it can be achieved also in columns operated with wash water, as was shown by Finch and Dobby (1991). In this work, $J_{\mathrm{b}}$ values were established by making tailing smaller than feed, without adding wash water.

Bias water $\left(J_{\mathrm{bw}}\right)$ will be called to the water added from the bottom of the column. Hence, negatives bias comes out simply from a difference between tailings and feed flow rates.

Fig. 1, shows gas hold up $\left(\varepsilon_{\mathrm{g}}\right)$ as a function of surface velocity of air $\left(J_{\mathrm{g}}\right)$ for the column filled with a solution of tall oil as well as for fluorite ore pulps in tall oil solutions.

As it is seen, from zero to $1.2 \mathrm{~cm} / \mathrm{s}$ of air, $\varepsilon_{\mathrm{g}}$ increases linearly, independent of frother concentration. Incidentally, hold up values reported here coincided with data published by Escudero and Tavera (2003) for low permeability stainless-steel spargers, in the absence of frother agent and at similar air velocities.

Above $1.2 \mathrm{~cm} / \mathrm{s}$ of air, the $50 \mathrm{ppm}$ and $100 \mathrm{ppm}$ solution curves show plateau which may result from surface tension

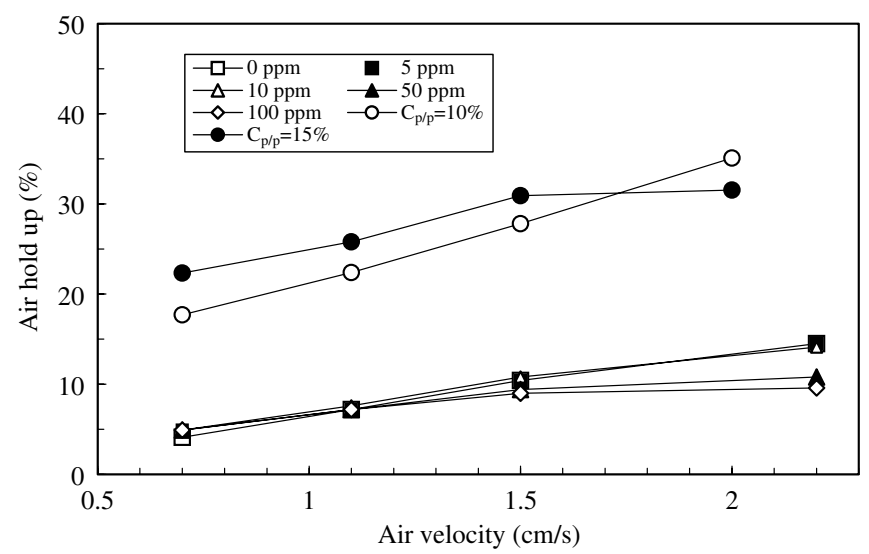

Fig. 1. Air hold up plotted as a function of surface velocity of air, $\left(J_{\mathrm{g}}\right)$, for tall oil solutions at different concentrations and water pulps with $300 \mathrm{~g} / \mathrm{ton}$ tall oil. effect on size distribution of bubbles (Finch and Dobby, 1990). For further discussion about critical surface tension on bubble size, Grau et al. (2005) may be read.

"Negative bias" flotation scheme was devised after Soto et al. (1991, 1993). The $\varepsilon_{\mathrm{g}}$ values for pulps were calculated from $\Delta H$ measurements obtained from water manometers readings. Water height differences were converted into mean air hold up values assuming that density of the pulp above the feeding point was same as concentrate and that pulp density at the bottom was similar to that of tailings. Also, it was assumed a linear relationship for the air hold ups along the column axis whose equation was used to calculate the average value, by integration, between those two points. This assumption seems reasonable since, in negative bias regime, the column is operated without froth layer. Hence, there is no sudden density change. In addition, the upper manometer was near the feed inlet and the lower manometer was close to tailing outlet. Hence, separation of manometers covered almost all the collection zone. Incidentally, Pérez et al. (2002) found such a linear relationship by conductivity measurements for a column with $3.68 \mathrm{~m}$ collection zone.

Air hold ups as a function of gas flow for fluorite pulps are plotted in Fig. 1 also. It is seen that, in the presence of slurry, air hold ups become considerably higher than those for pure solutions. It seems that negative bias is responsible for such a significant increase due to downward flows reduction as a result of feed water overflow. In addition, as the fraction of floatable mineral in the feed was quite high (about $68.7 \% \mathrm{CaF}_{2}$ ), it seems that heavily loaded bubbles get critically low uprising velocities in the collection zone, provoking such abnormally high hold up values.

Pérez et al. (2002) demonstrated that, in a column with a froth layer of $30 \mathrm{~cm}$, air hold ups vary with height of collection zone as well. They found that, for silica pulps lower than $25 \%$ solid, hold ups (volume of air plus solid) increased as the size of the collection zone increased. On the contrary, for particle contents greater than $25 \%$, the effects were reverted and accordingly hold ups decreased in longer collection zone.

In order to substantiate negative bias effect, a flow of water was injected at $31.5 \mathrm{~cm}$ above the sparger, with the aim of increasing concentrate flow while keeping $J_{\mathrm{b}}\left(J_{\mathrm{t}}-\right.$ $J_{\mathrm{f}}$ ) constant. The results are shown in Fig. 2 where air hold ups are plotted against bias water $\left(J_{\mathrm{bw}}\right)$ for two different air velocities for $10 \%$ solid pulps. The difference between tail and feed was kept constant in $-0.3 \mathrm{~cm} / \mathrm{s}$ for all tests. Water injected from the bottom varied from zero to $1.5 \mathrm{~cm} / \mathrm{s}$. The actual effect of this water was to increase the flow rate of the concentrate. It is important to remark that flotation was carried out without the formation of a froth layer.

It is seen from this figure that, air hold ups decreases as water added from the bottom increases. Such a decrease might result from the reduction of the actual downward flow of pulp in the collection zone, by the water addition since an equivalent amount of water had to come out through the overflow of the column due to that tailing flow 


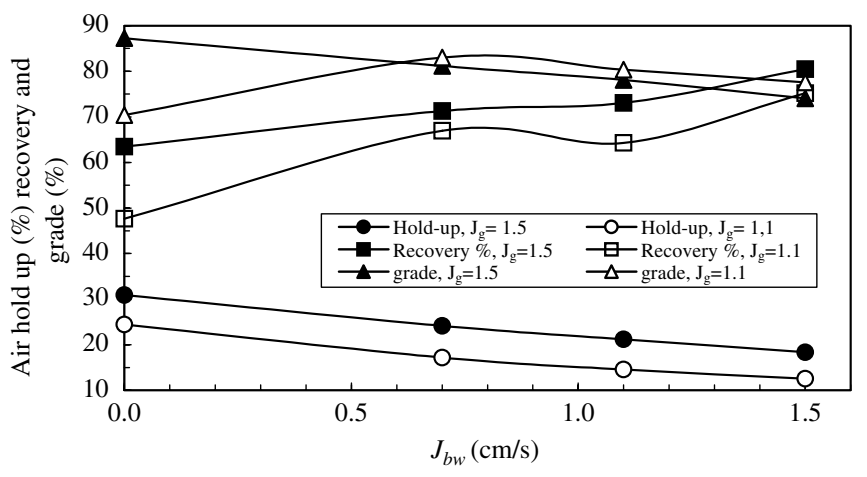

Fig. 2. Air hold up and $\mathrm{CaF}_{2}$ recovery and grade (\%) as a function of bias water velocity $\left(J_{\mathrm{bw}}\right)$ injected at the bottom of the column, for two air velocities $\left(J_{\mathrm{g}}\right)$. Mineral ground for $20 \mathrm{~min}$. Flotation with $300 \mathrm{~g} /$ ton tall oil $\left(C_{p / p}=10 \%\right)$.

rate was kept constant. It is seen that, hold up tends to a value similar to that of pure solution as can be deduced comparing these values with those of Fig. 1.

It seems that, water addition counterbalance the decrease in uprising velocity due to particle attachment resulting in a bubbles residence time reduction in the collection zone. Consequently, recovery of fluorite increases as flow rate of water injected augmented. In addition, recovery of fluorite also increases as a function of $J_{\mathrm{g}}$. This fact supports the idea that the increase in recovery due to water addition results from an increase in uprising velocity since the same effect is obtained either increasing the number of bubbles (through $J_{\mathrm{g}}$ ) or injecting water.

\section{Conclusions}

- Column flotation, operated under negative bias, is able to concentrate fluorite.

- The best results are obtained when water is added from the bottom of the column.
- Hold ups reach values similar to the one obtained with pure solutions.

- Also, recovery increases as water addition increases.

- On the other hand, grade decreases as water flow increases.

- From here it can be said that, column act as a rougher flotation machine.

\section{Acknowledgements}

The authors would like to thank to the General Manager of Nossa Senhora do Carmo Mines, from Criciúma, Mr. Carlos Sartor, for his enthusiastic support to this work and the Chief Engineer Mr. Julio Gomes for his invaluable help.

\section{References}

Escudero, R., Tavera, F.J., 2003. Predicting gás hold-up in flotation columns from the physical characteristics of rigid spargers. Trans. Institut. Mining Metallurg., Sec. C 111, C143-C148.

Finch, J.A., Dobby, G.S., 1990. Column Flotation. Pergamon Press (a: paragraph 5.2.2; b: paragraph 2.1.2.2; c: paragraph 2.1.1; d: paragraph 5.2; e: paragraph 2.2.2.6; f: paragraph 5.5.1).

Finch, J., Dobby, G., 1991. Column flotation, a selected review. Int. J. Miner. Process. 33, 343-354.

Grau, R.A., Laskowski, J.S., Heiskanen, K., 2005. Effect of frother on bubble size. Int. J. Miner. Process. 76, 225-233.

Pérez G., R., Gallegos A., P.M., Uribe S., A., Nava A., F., 2002. Effect of collection zone height and operating variables on recovery of overload flotation columns. Miner. Eng. 15, 325-331.

Rubinstein, J.B., 1995. Column Flotation, Processes, Design and Practices. Gordon and Breach Science Publishers (a: Paragraph 2.1; b: Paragraph 2,4; c: Paragraph 2.3).

Soto, H., Aliaga, W., 1993. Application of column cells to potash flotation in brines. Trans IMM/Sect. C, c170-c174.

Soto, H., Barbery, G., 1991. Flotation of coarse particles in a countercurrent column cell. Miner. Metallurg. Process., 16-21.

Taggart Arthur F., 1954. Handbook of Mineral Dressing, p. 13 (Chapter 12). 